\title{
c面GaN基板上可視光半導体レーザーの開発
}

\author{
三好隆, 長濱 慎一, 向井 孝志 \\ 日亜化学工業 (株) 第二部門開発本部 窒化物半導体研究所 ( T774-8601 徳島県阿南市上中町岡491番地)
}

\section{Development of Visible Range Semiconductor Laser Diodes Grown on c-Plane GaN Substrate}

Takashi MIYOSHI, Shin-ichi NAGAHAMA, and Takashi MUKAI

Nitride Semiconductor Research Laboratory, R\&D Division, Optoelectronics Products BU, Nichia Corporation, 491 Oka, Kaminaka-cho, Anan-shi, Tokushima 774-8601

(Received November 30, 2009)

\begin{abstract}
This paper reports development and characteristics of visible range nitride based semiconductor laser diodes (LDs) grown on c-plane free-standing GaN substrates by Metal Organic Chemical Vapor deposition (MOCVD). In blue regions, $1 \mathrm{~W} 445 \mathrm{~nm}$ LDs have been developed for laser projection display. In blue-green regions, $488 \mathrm{~nm}$ LDs have been developed for the replacement with Ar-ion lasers or diode pumped solid state (DPSS) lasers. Moreover, we succeeded in developing green LDs with the wavelength in $518 \mathrm{~nm}$ by improving the growth condition of epitaxial layers and structures of LDs.
\end{abstract}

Key Words: Visible range, Laser diodes, Blue, Green

\section{1. はじめに}

ウルツ鉱型の結晶構造を持つ $\mathrm{GaN}, \mathrm{AlN}, \mathrm{InN}$ からな るIII族窒化物半導体は, 深紫外〜赤外まで $(0.8-6.4 \mathrm{eV})$ のワイドバンドギャップをカバーする化合物半導体であ

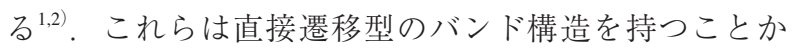
ら発光デバイスとして広く利用されており，これまでに 高輝度青色, 緑色発光ダイオード (LED), 固体照明用白 色光源などが実現, 実用化されている. 半導体レーザー (Laser Diode; LD)については1996年に世界初のレーザー 発振が報告され3), 現在では波長405 nmの青紫色LDがブ ルーレイに代表される次世代光ディスク用の光源として 利用されている。また近年では発振波長の広帯域化や光 出力の高出力化により ${ }^{4-6)}$, 光ディスク以外の分野にも その用途を広げている.

本稿ではそれらの中でも最近特に開発が進められてい る，青〜緑色に渡る可視光領域のLDに関して報告す る。青色領域では大型ディスプレイ用途に向けて波長 $445 \mathrm{~nm}$, 光出力 $1 \mathrm{~W}$ 以上の高出力, 高効率のLDを作製

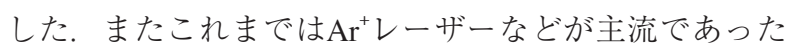
バイオ用途向け光源の置き換えとして波長 $488 \mathrm{~nm}$ のD, 更には小型プロジェクタ向けに510 nmを越す緑色領域 のLD開発に成功した。

\section{III族窒化物LDの長波長化}

III族窒化物半導体では初のレーザー発振波長が $410 \mathrm{~nm}$ あっあたことが示すように゙), 一般に400〜 $420 \mathrm{~nm}$ の青紫色領域が比較的LDを作りやすい波長帯と 考えられる。これは活性層 (主に $\mathrm{InGaN}$ ) やクラッド層 (主に $\mathrm{AlGaN}$ ) と基板である $\mathrm{GaN}$ との格子定数差が小さ く, 比較的容易にエピタキシャル成長出来るためであ る。一方筆者らはより長波長である可視光領域のLD実 現を目的として，開発に取り組んできた。Fig. 1はこれ までに報告されたc面 $\mathrm{GaN}$ 基板上窒化物LDにおけるしき い值電流密度の発振波長依存性である ${ }^{7-9}$. LDのしきい

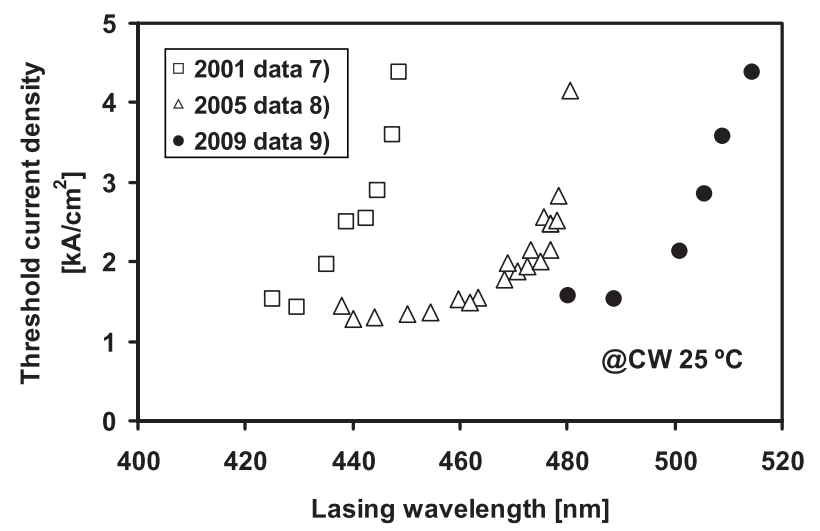

Fig. 1 Lasing wavelength dependence of the threshold current density of LDs under $\mathrm{CW}$ operation at $25^{\circ} \mathrm{C}$. 
值電流密度は発振波長に大きく依存し, 長波長化に伴い 上昇していくことがわかる。 これは主に基板との格子定 数差の増大に伴う InGaN活性層の結晶劣化や内部電界 ${ }^{10,11)}$ による発光効率の低下，屈折率の波長分散に起因したエ ピタキシャル層内での光閉じ込めの低下などが原因とし て挙げられる。これらは長波長化に伴い影響がより大き くなり，LDを長波長化する際の壁となる。しかしなが ら筆者らはこれらに対し, 高品質自立 $\mathrm{GaN}$ 基板 ${ }^{12,13)}$ の採 用やエピタキシャル成長条件, 光閉じ込め構造の最適化 等により，発振波長の長波長化を達成してきた。その結 果現時点では $510 \mathrm{~nm}$ を越す緑色領域でのレーザー発振 が可能となっている. 加えて500 nm以下では, $440 \mathrm{~nm}$ 以下の短波長領域と比較してもしきい值電流密度の上昇 は発生して扮らず, 長波長領域に扔いても短波長同様に 高効率, 高出力のLDが作製可能であることを示してい る.

\section{LDの作製方法}

Fig. 2に作製したLDの構造概念図を示す，基板として は低転位密度のn型導電性を有するc面自立 $\mathrm{GaN}$ 基板を用 い, 有機金属気相成長法 (Metal Organic Chemical Vapor Deposition; MOCVD)によりエピタキシャル成長を行っ た。構造としては発光層である $\mathrm{InGaN}$ 活性層を中心とし て成長方向にガイド層, クラッド層で挟み込んだ分離閉 じ込めへテロ構造 (Separate Confinement Heterostructure; $\mathrm{SCH})$ である。また導波路はリッジ構造とし, 共振器端 面はウェハーをm面でへき開することで作製した。波長 については主に活性層であるInGaNの組成を変化させる ことにより制御した。

\section{4. 窒化物可視光LD}

\section{1 高出力青色LD}

ディスプレイ用青色光源として要求される波長は440 〜 460 nm程度である。我々はLDの波長を445 nmとし,

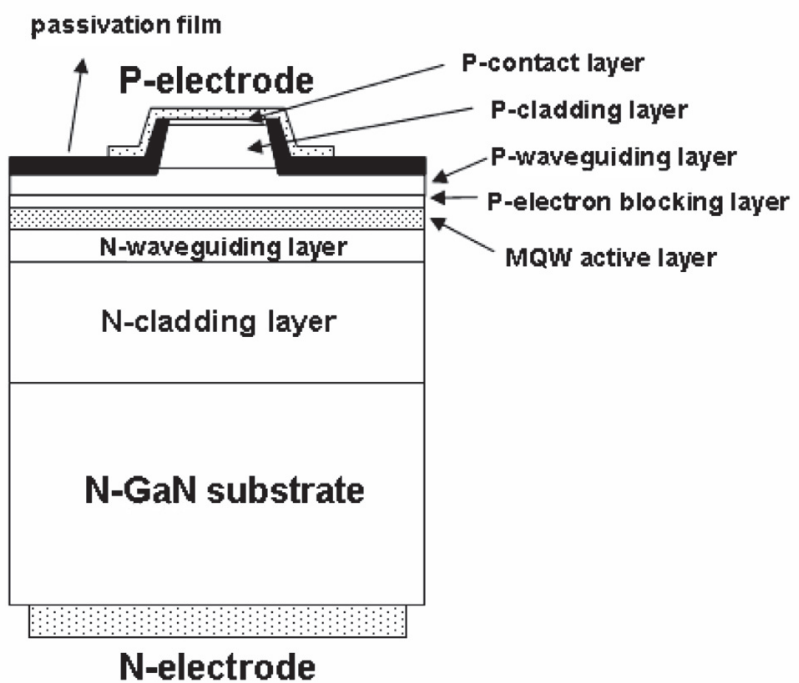

Fig. 2 Schematic structures of LDs.

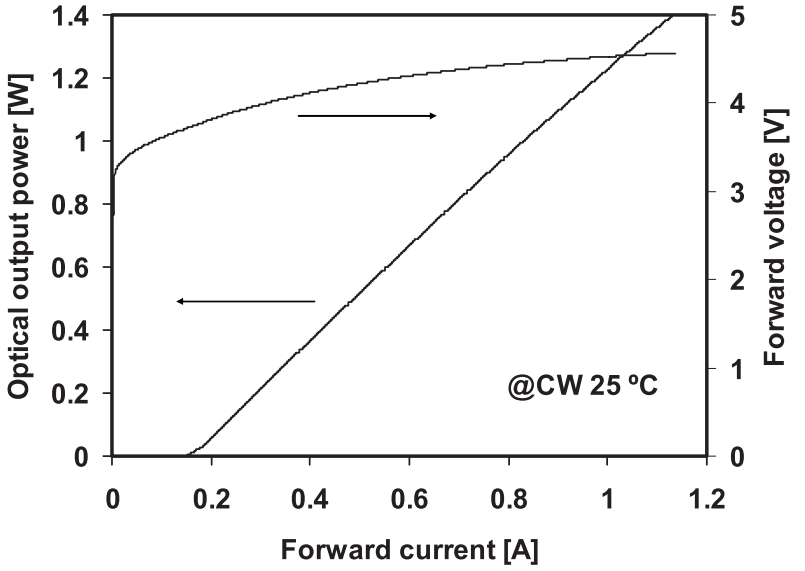

Fig. $3 V-I, L-I$ characteristics of the blue LD under CW operation at $25^{\circ} \mathrm{C}$.

高出力化を図った.リッジ幅については高出力駆動時に 懸念されるレーザー端面の光学損傷 (Catastrophic Optical Damage; COD) を抑制するため, 光ディスク向けレー ザー(リッジ幅3 $\mu \mathrm{m}$ 以下)に比べてリッジ幅を拡大した ワイドストライプ構造(リッジ幅 $15 \mu \mathrm{m})$ とした

Fig. 3に作製した青色LDの電流 - 電圧 $(V-I)$, 電流 - 光 出力 $(L-I)$ 特性を示す。測定はLDのケース温度を $25^{\circ} \mathrm{C}$ と し，連続駆動 $(\mathrm{CW})$ の条件下で行った。図よりしきい值 電流は $152 \mathrm{~mA}$ ，電流1 Aを流したときの光出力および電 圧值はそれぞれ $1.23 \mathrm{~W} ， 4.5 \mathrm{~V}$ であった。ここから見積 もられる電力 - 光変換効率 (Wall- Plug Efficiency; WPE) は27.3\%であった。次に青色LDの $1 \mathrm{~W}$ 光出力時のスペク トルと遠視野像 (Far Field Pattern; FFP) をFig. 4，5に示 す。Fig. 4から発振波長は445 nmであり, 縦マルチモー ドで発振していることが分かる。またFFPについては結 晶成長面に対して垂直 $\left(\theta_{\perp}\right)$, 水平方向 $\left(\theta_{\| /}\right)$で形状が大き く異なることがわかる．垂直方向については基本モード で発振しているためガウス形状であるが，水平方向はワ イドストライプ構造であることから高次モードの発生に よりマルチモード化し，台形状の放射モードとなってい る。広がり角は強度がピークの $1 / \mathrm{e}^{2}$ となる角度で定義し た場合，垂直方向が $40.9^{\circ}$ ，水平方向が $12.8^{\circ}$ の縦方向に

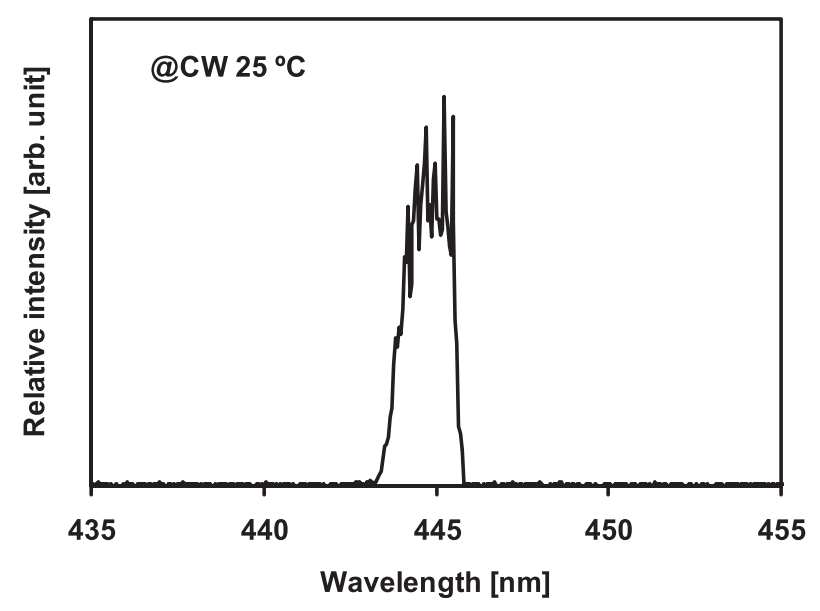

Fig. 4 Lasing spectrum of the blue LD with an output power of $1 \mathrm{~W}$ under $\mathrm{CW}$ operation at $25^{\circ} \mathrm{C}$. 


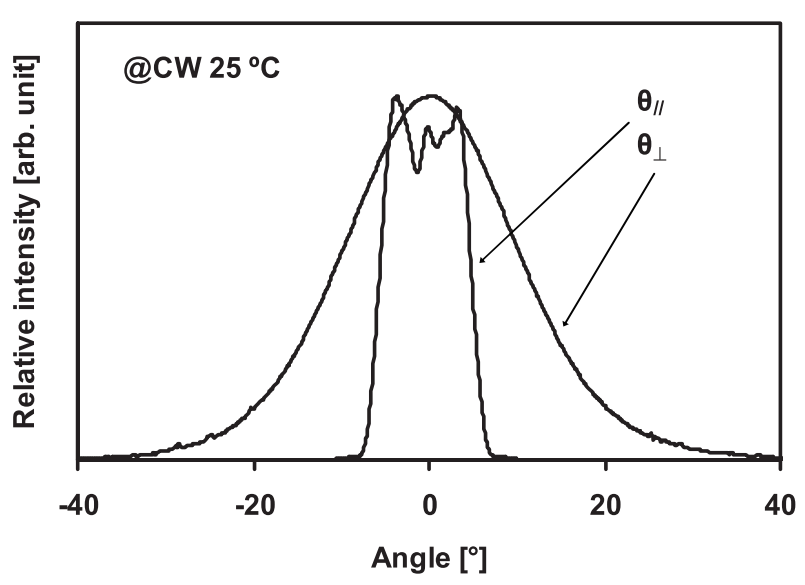

Fig. 5 FFPs of the blue LD with an output power of $1 \mathrm{~W}$ under $\mathrm{CW}$ operation at $25^{\circ} \mathrm{C}$.

長い放射形状となる.

次に作製したLDをパルス電流( パルス幅: $2 \mu \mathrm{s}$, デューティー：1\%)で駆動した場合のL-I特性をFig. 6に 示す. パルス電流で駆動した場合, 光出力 $3 \mathrm{~W}$ まで駆動 することを確認した。この結果は作製したLDのCOD等

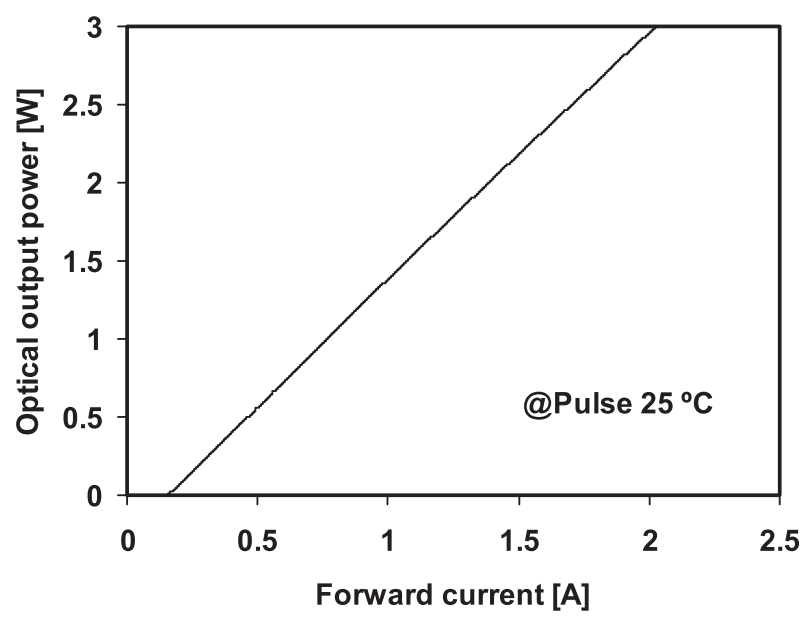

Fig. $6 L-I$ characteristic of the blue LD the pulsed current condition (pulse width: $2.0 \mu \mathrm{s}$, pulse duty: $1 \%$ ).

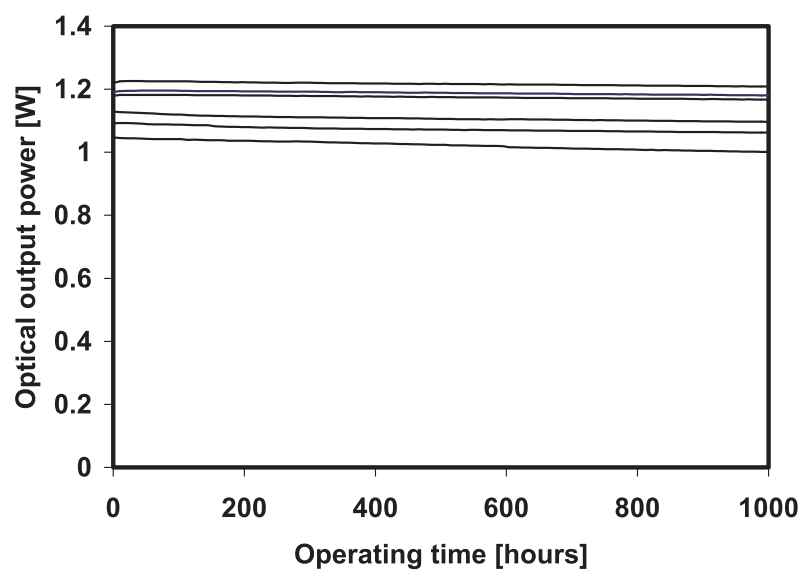

Fig. 7 Results of the lifetime test of CW-operated blue LDs under ACC condition with an operating current of $1 \mathrm{~A}$ at $25^{\circ} \mathrm{C}$.
による破壊レベルが非常に高いことを示唆しており， $\mathrm{GaN}$ 系材料の堅牢さを示す結果であると考えられる。

青色LDの寿命についてはディスプレイ用途を考慮し， LDを一定電流で駆動(駆動電流值：1A， Auto Current Control; ACC) した際の光出力の経時変化から見積もり を行った (Fig. 7)。 ケース温度を $25^{\circ} \mathrm{C}$ と, 寿命を光出 力が初期の半分になる期間 (半減期) と定義した場合, 1000 時間後の劣化係数 $(=\Delta L / \Delta t)$ より平均の推定半減期 は3万時間以上と見積もられた。長寿命が要求される大 型ディスプレイ用途にも十分適用可能であると考えられ る.

\section{2 バイオ向け488 nmLD}

波長488 nmのレーザー光は主に医療やバイオ分野の 計測用途に用いられる光源である。従来この波長帯の

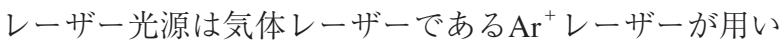
られてきたが, 近年では機器の小型化の点で有利である 波長変換型の半導体励起固体 (Diode Pumped Solid State; DPSS）レーザーへの置き換えが進んでいる。一方LDの 場合, 非常に小型の光源から直接 $488 \mathrm{~nm}$ のレーザー光 が得られるため機器の構成が非常にシンプルとなる。ま た電流制御による光出力の直接変調が可能である, 消費 電力が小さい, 光源の取り扱いが容易であるなど多くの メリットがあり，既存光源の置き換えが期待される。そ こで我々はIII族窒化物半導体をベースとして, 高出力か つ信頼性の高い波長488 nmのLDを作製した。

$488 \mathrm{nmLD}$ の基本構造はFig. 1で示した青色LDと同様 のリッジストライプ構造である。エピ構造については発 振波長の長波長化に合わせて，主に活性層成長条件を最

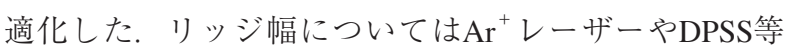
と同様の高いビーム品質を要求されることから, 光ディ スク用LDと同様の狭ストライプ構造 $(2 \mu \mathrm{m})$ とした。

Fig. 8 に88 nmLDの典型的なV-I, L-I特性を示す. ケース温度 $25^{\circ} \mathrm{C}, \mathrm{CW}$ 駆動時のしきい值電流は30 mAで あり, 光出力 $60 \mathrm{~mW}$ 時の電流及び電圧值はそれぞれ

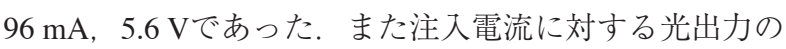
非線形性(キンク)は80 mWまで発生しておらず，横モー ドの安定性が高いことを示唆している. また光出力

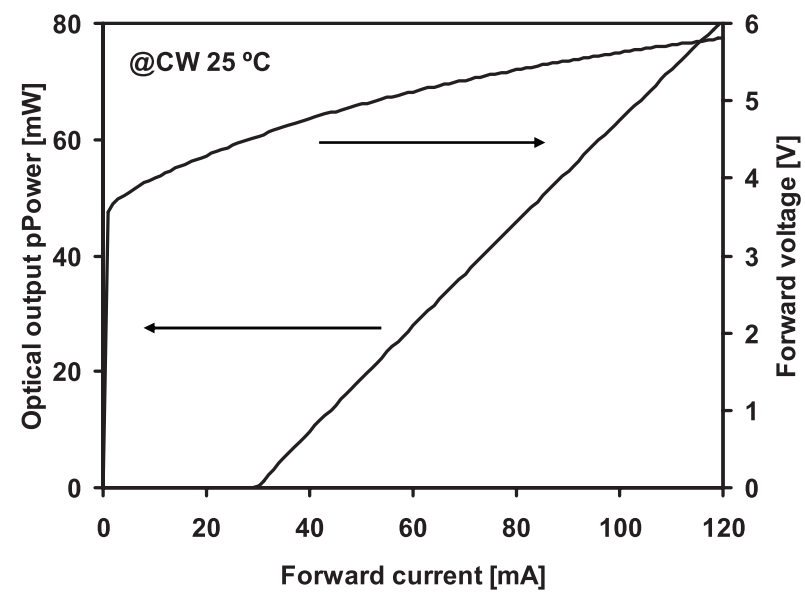

Fig. $8 V-I, L-I$ characteristics of the $488 \mathrm{~nm}$ LD under $\mathrm{CW}$ operation at $25^{\circ} \mathrm{C}$. 


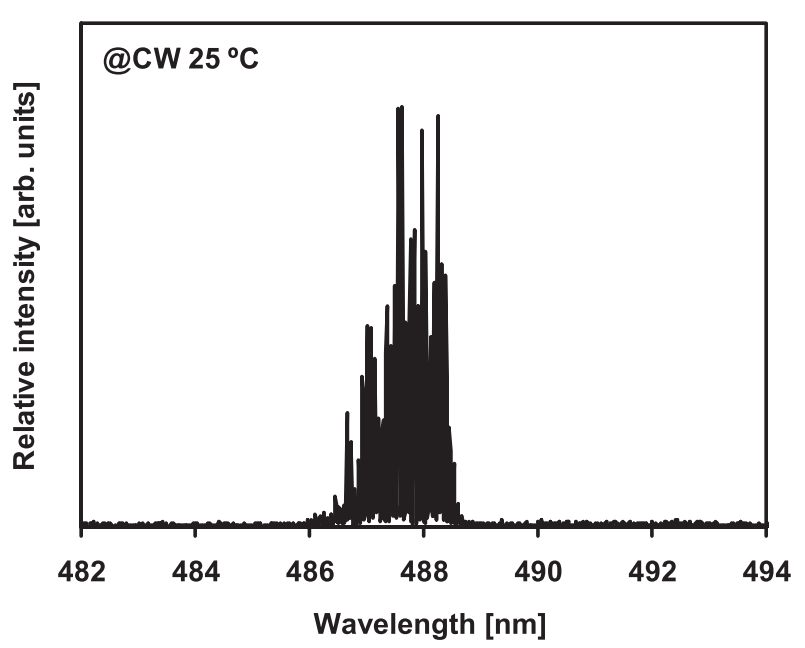

Fig. 9 Lasing spectrum of the $488 \mathrm{~nm} \mathrm{LD}$ with an output power of $60 \mathrm{~mW}$ under $\mathrm{CW}$ operation at $25^{\circ} \mathrm{C}$.

60mW時の発振スペクトル及びFFPをFig. 9及び10に示 す。スペクトルより発振波長は $488 \mathrm{~nm}$ であり，青色LD と同様に縦マルチモードで発振していることがわかる. FFPについては狭ストライプ構造であるため水平方向に ついても基本モードでの発振を示すガウス形状となって おり, レンズ等によるビーム整形や集光も容易と考えら れる。広がり角についてはピーク強度の半值全幅 (Full Width at Half Maximum; FWHM) で定義した場合, 水平方 向が $10^{\circ}$ ，垂直方向が $23.5^{\circ}$ であった，寿命特性について

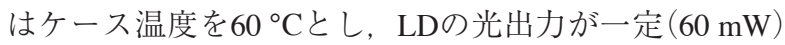
となるように駆動 (Auto Power Control; APC) し，評価を 行った(Fig. 11)。この場合電流值が初期の1.3倍となる 時間を寿命と定義すると, 2000 時間通電後の劣化係数 $(\Delta I / \Delta t)$ より平均寿命は 10,000 時間以上と見積もられ た。従来光源の置き換えとして十分な信頼性であると考 えられる。

\section{3 小型プロジェクタ向け緑色LD}

近年LEDやレーザーを光源とする小型プロジェクタが 着目されており，LEDに関しては既に実用化段階であ

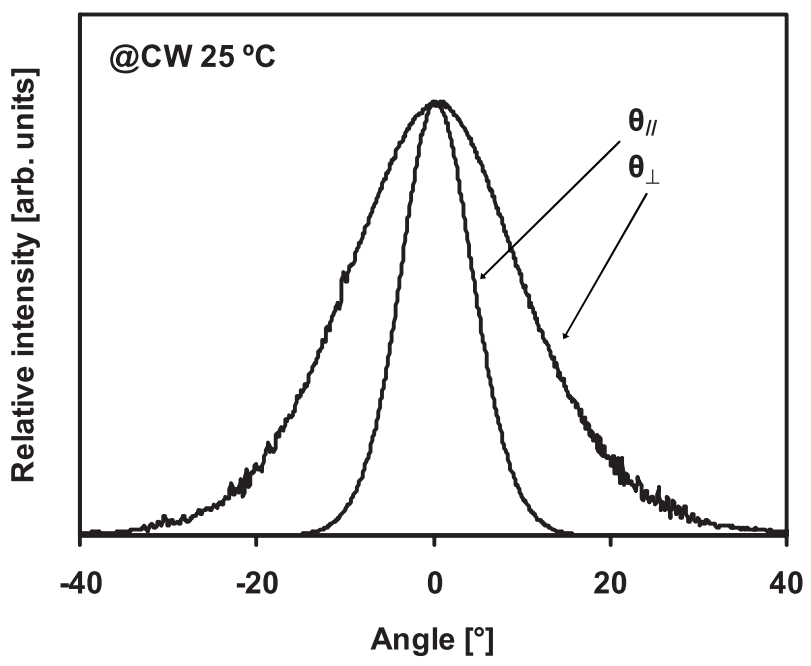

Fig. 10 FFPs of the $488 \mathrm{~nm} \mathrm{LD}$ with an output power of 60 $\mathrm{mW}$ under $\mathrm{CW}$ operation at $25^{\circ} \mathrm{C}$.

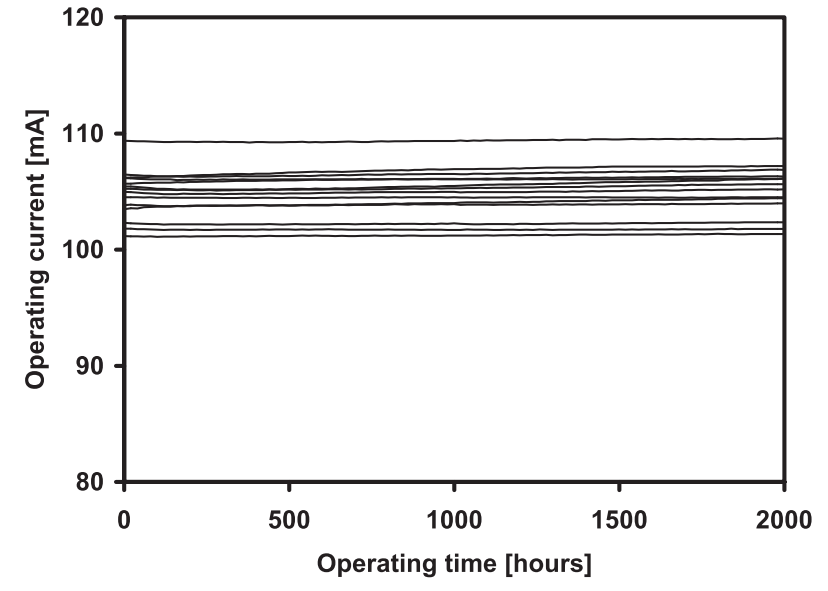

Fig. 11 Results of the lifetime test of CW-operated $488 \mathrm{~nm}$ LDs under APC condition with an output power of $60 \mathrm{~mW}$ at $60^{\circ} \mathrm{C}$.

る。レーザーを光源とした場合, 既存光源に比べて単色 性が高く色再現範囲が拡大する, 発光点が小さいことか ら光学系の更なる小型化が可能である, 更には高画質化 の可能性があるなどから今後の実用化が期待されてい る。レーザーを光源としたデバイスの場合, フルカラー 化のためには赤，青，緑の光源が必要となるが，このう ち赤, 青についてはそれぞれAlInGaP系, InGaN系のLD が実用化されている。一方緑についてはII-VI族化合物 半導体を用いたLDに関する報告はある ${ }^{14,15}$ が，現時点で 実用化されているものは無く，2次高調波発生 (Second Harmonic Generation; SHG) を用いた波長変換型のレー ザーが用いられている。そこで筆者らは3原色すべてを LD化することを目的としてIII族窒化物半導体を用いて 発振波長を長波長化し， $510 \mathrm{~nm}$ 越す緑色領域でのLD を実現した。

緑色LDの構造については488 nm帯のレーザーと同様 の狭ストライプ構造である。基板については現在様々な 面方位を用いた長波長化のアプローチがなされている ${ }^{16-18)}$ が，筆者らは他の波長帯と同様にc面 $\mathrm{GaN}$ 基板を用い た。エピについては長波長化の際に問題となる活性層の 結晶劣化 7 を抑えるよう, 成長条件や構造の最適化を 行った

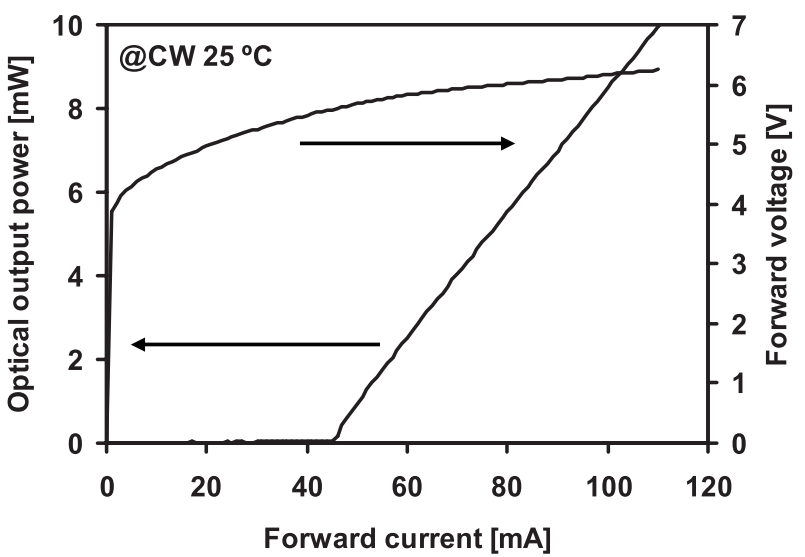

Fig. 12 V-I, L-I characteristics of the green LD under CW operation at $25^{\circ} \mathrm{C}$. 


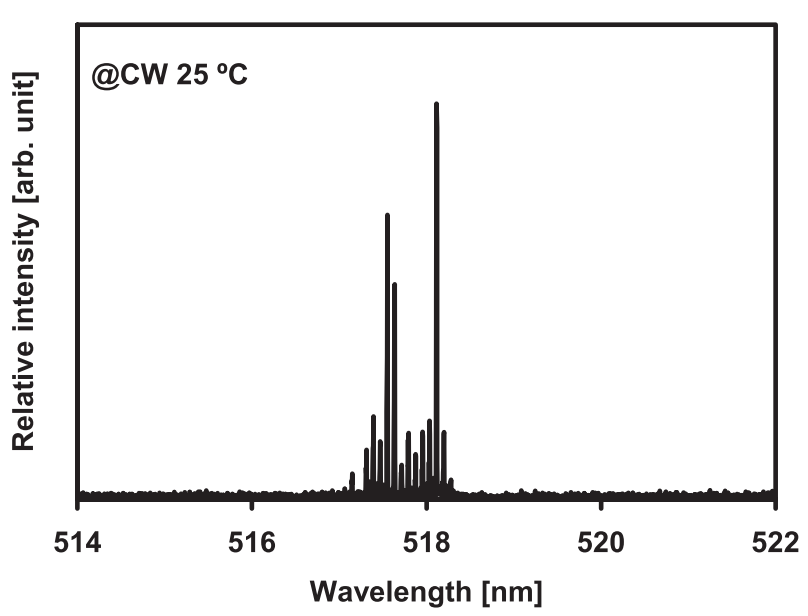

Fig. 13 Lasing spectrum of the green LD with an output power of $5 \mathrm{~mW}$ under $\mathrm{CW}$ operation at $25^{\circ} \mathrm{C}$.

Fig. 12に作製したLDの電流 - 電圧 $(V-I)$, 電流 - 光出 力 $(L-I)$ 特性を示す. しきい值電流は $45 \mathrm{~mA}$, 光出力 $5 \mathrm{~mW}$ 時の電流及び電圧值はそれぞれ78 mA, $6.0 \mathrm{~V} て ゙$ あった. また光出力 $5 \mathrm{~mW}$ 時の発振スペクトル及びFFP をFig. 13及び14に示す。スペクトルより発振波長は $518 \mathrm{~nm}$ であり，他の波長と同様に縦マルチモードで発 振している. FFPについては基本的にはガウス形状と なっているが, 垂直方向に若干波形の乱れが確認され る。これは長波長化に伴う光閉じ込めの低下によって垂 直方向に光のもれが発生していることが原因と考えられ る。広がり角についてはFWHMに拈い, 水平方向が $10.4^{\circ}$ ，垂直方向が $22.5^{\circ}$ であった。寿命特性については $488 \mathrm{~nm}$ 帯と同様にAPC駆動で評価を行った(Fig. 15). ケース温度についてはモバイル用途を考慮し, $80^{\circ} \mathrm{C}$ と した. 光出力 $5 \mathrm{~mW}$ の場合, 1500 時間通電後の劣化係数 $(\Delta I / \Delta t)$ から寿命は5000時間以上と見積もられた。

\section{5. まとめ}

本稿ではc面 GaN基板上に作製した青〜緑色領域の窒 化物LDに関して述べた。青色領域では光出力 $1 \mathrm{~W}$ 越す 高出力, 高効率のLDが得られた. $488 \mathrm{~nm}$ 帯では既存光

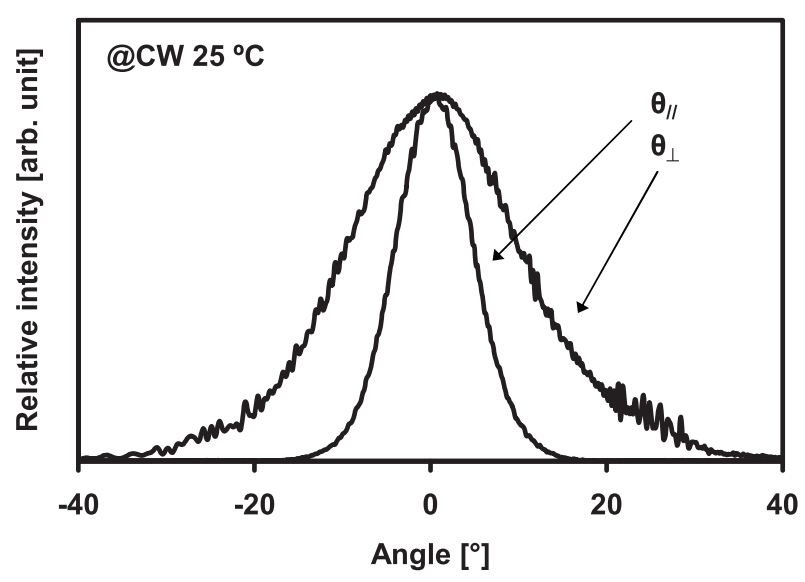

Fig. 14 FFPs of the green LD with an output power of 5 $\mathrm{mW}$ under $\mathrm{CW}$ operation at $25^{\circ} \mathrm{C}$.

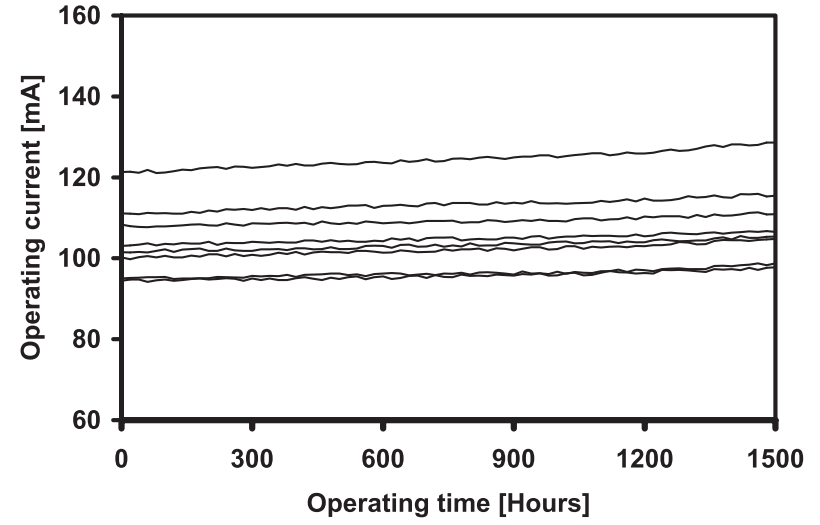

Fig. 15 Results of the lifetime test of CW-operated green LDs under APC condition with an output power of $5 \mathrm{~mW}$ at $80^{\circ} \mathrm{C}$.

源を置き換え可能な高出力，かつ信頼性の高いLDを作 製した。また窒化物LDで518 nmの発振を確認した。今 後の課題としては更なる長波長化, 高効率化と考えられ る.

\section{参考文献}

1) T. Matsuoka, H. Okamoto, M. Nakao, H. Harima, and E. Kurimoto: Appl. Phys. Lett. 81 (2002) 1246.

2) J. Wu, W. Walukiewicz, K. M. Yu, J. W. Ager III, E. E. Haller, H. Lu, W. J. Schaff, Y. Saito, and Y. Nanishi: Appl. Phys. Lett. 80 (2002) 3967

3) S. Nakamura, M. Senoh, S. Nagahama, N. Iwasa, T. Yamada, T. Matsushita, H. Kiyoku, and Y. Sugimoto: Jpn. J. Appl. Phys. 35 (1996) L74.

4) S. Masui, Y. Matsuyama, T. Yanamoto, T. Kozaki, S. Nagahama, and T. Mukai: Jpn. J. Appl. Phys. 42 (2003) L1318.

5) S. Nagahama, Y. Sugimoto, T. Kozaki, and T. Mukai: Proc. SPIE 5738 (2005) 57.

6) T. Kozaki, H. Matsumura, Y. Sugimoto, S. Nagahama, and T. Mukai: Proc. SPIE 6133 (2006) 613306.

7) S. Nagahama, T. Yanamoto, M. Sano, and T. Mukai: Jpn. J. Appl. Phys. 40 (2001) 3075.

8) T. Kozaki, T. Yanamoto, T. Miyoshi, Y. Fujimura, S. Nagahama, and T. Mukai: SID 2005 Digest, Boston, May, 2005, p.1605.

9) T. Miyoshi, S. Masui, T. Okada, T. Yanamoto, T. Kozaki, S. Nagahama, and T. Mukai: Appl. Phys. Express 2 (2009) 062201.

10) S. Chichibu, T. Azuhata, T. Sota, and S. Nakamura: Appl. Phys. Lett. 69 (1996) 4188.

11) T. Takeuchi, S. Sota, M. Katsuragawa, M. Komori, H. Takeuchi, H. Amano, and I. Akasaki: Jpn. J. Appl. Phys. 36 (1997) L382.

12) S. Nagahama, N. Iwasa, M. Senoh, T. Matsushita, Y. Sugimoto, H Kiyoku, T. Kozaki, M. Sano, H. Matsumura, H. Umemoto, K. Chocho, and T. Mukai: Jpn. J. Appl. Phys. 39 (2000) L647.

13) K. Motoki, T. Okahisa, N. Matsumoto, M. Matsushima, H. Kimura, H. Kasai, K. Takemoto, K. Uematsu, T. Hirano, M. Nakayama, S. Nakahata, M. Ueno, D. Hara, Y. Kumagai, A. Koukitu, and H. Seki: Jpn. J. Appl. Phys. 40 (2001) L140.

14) J. M. Gaines, R. R. Drenten, K. W. Haberern, T. Marshall, P. Mensz, and J. Petruzzello: Appl. Phys. Lett. 62 (1993) 2462.

15) M. A. Haase, P. F. Baude, M. S. Hagedorn, J. Qiu, J. M. DePuydt, H. Cheng, S. Guha, G.E. Höfler, and B. J. Wu: Appl. Phys. Lett. 63 (1993) 2315.

16) K. Okamoto, J. Kashiwagi, T. Tanaka, and M. Kubota: Appl. Phys. Lett. 94 (2009) 071105.

17) Y. Enya, Y. Yoshizumi, T. Kyono, K. Akita, M. Ueno, M. Adachi, T. Sumitomo, S. Tokuyama, T. Ikegami, K. Katayama, and T. Nakamura: Appl. Phys. Express 2 (2009) 082101.

18) Y. Yoshizumi, M. Adachi, Y. Enya, T. Kyono, S. Tokuyama, T. Sumitomo, K. Akita, T. Ikegami, M. Ueno, K. Katayama, and T. Nakamura: Appl. Phys. Express 2 (2009) 092101. 